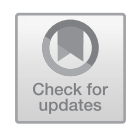

\title{
The Death of Indie Hip-Hop?: The Blurry Lines Between the Majors and Independent Hip-Hop
}

\begin{abstract}
This chapter utilizes forty-six interviews with self-identified independent hip-hop listeners to navigate the changing meanings of indie hip-hop in the post-golden era. The author elaborates on listener's definitions of independent and mainstream hip-hop and analyzes their interpretations of race, class, gender, sexual orientation, and oppositional consciousness. Listeners suggest that indie hip-hop often focuses on race and class but often ignores issues of gender and sexuality. Female and queer listeners are more conscious of this omission than male and straight listeners, despite a current push toward female and LGBTQ representation in hip-hop's mainstream. Also, there remains a blurry line between independents and majors that many artists navigate as they attempt to retain economic and creative freedom while still attempting to become financially successful. Technological shifts and advances, such as marketing and distribution channels, have further exacerbated the blurry lines of hip-hop.
\end{abstract}

Keywords Authenticity - Race and class - Gender and sexuality • Technological advancements in hip-hop · Independent hip-hop movement

A-Trak, a renowned DJ, producer, artist, and founder of the record label Fool's Gold, stated on Medium's Cuepoint that hip-hop's "left field seeped out of the margins and into the mainstream" (A-Trak 2014).

(C) The Author(s) 2019

C. Vito, The Values of Independent Hip-Hop in the Post-Golden Era, https://doi.org/10.1007/978-3-030-02481-9_4 
He claimed that the way we are listening to music has changed over the past 15 years, and it is becoming clear that hip-hop's major and independent musicians are becoming more intertwined than ever. David, an independent hip-hop listener, echoes A-Trak's sentiments: "ironically the same indie emcees I used to listen to are now active in the mainstream market...(and) the emcees I've heard attack mainstream artists are now trying to be signed."

Unlike previous chapters (Chapters 2 and 3) that focused on artists' lyrics, this chapter examines how listeners interpret and navigate the changing landscape and increasingly blurry differences between major and independent hip-hop following the culture's push toward independence from 2000 to 2013 , particularly in relation to race, class, gender, and sexual politics. My analysis draws on forty-six in-person and online interviews with self-identified independent hip-hop listeners of which two are also indie musicians themselves. The respondents range from the age of 18 to 35 living in Southern California and represent a heterogeneous snowball sample with regard to gender, sexual orientation, race/ethnicity, income, self-defined social class, educational attainment, and political affiliation (see Chapter 1 and Appendix C). The age demographic represents the population that was highly influenced by hip-hop in the post-golden era and analyzes their interpretations of hip-hop and hip-hop music in that time period.

My analysis below emphasizes three main themes. Interviewees indicate that the traditional definitions of major and independent remain intact. They corroborate indie hip-hop's claims that record label affiliation remains salient to the bifurcation between mainstream and indie culture. Listeners help create a notion of authenticity for musicians through their interpretations of artists' messages regarding race, class, gender, and sexual orientation. In particular, they state that mainstream musicians' messages often do not reflect their social locations and experiences. Rather, male indies of color present lyrics that reflect the struggles of the listeners in regard to race and class; yet claims of authenticity remain vexed as respondents believe that much of independent hip-hop often ignore issues of gender and sexuality despite the increased diversity of artists and listeners. Thus, female and LGBTQA (alliance) respondents highlight artists concordant with their social identities, which helps destabilize the conceptions of authenticity as technology allows for a wider array of the population to produce and consume music. 
Also, the results show that the line between the majors and independents has become increasingly blurred following hip-hop's push for independence in the early 2000s. Hip-hop culture is not viewed as binary oppositions, but rather as fluid and constantly changing as performers attempt to retain economic and creative freedom while still attempting to become financially successful. For instance, listeners recognize that large corporations frequently pull from the indie market and musicians are often pushed into the majors by financial motives. This has led to many indie acts and labels to navigate between the two markets in different ways as they try to further their careers.

Finally, respondents discuss waves of commodification and resistance in the "indie" movement. They state that a period of resistance followed the mass commodification of hip-hop in the early 2000s. Currently, major advances in technology have allowed artists to become commercially successful without the aid of large corporations. Even so, interviews reveal that they still remain intensely intertwined with major companies in old and new ways to utilize their marketing and distribution channels. Ultimately, independent hip-hop listeners express the complexity of the music industry and hip-hop culture.

\section{Perceived Distinctions Between the Majors AND INDEPENDENT Hip-HoP}

Interviews indicate that record label status remains a key characteristic in hip-hop culture today. While label status remains salient, artists' access to economic and cultural resources remains a key issue. My results also find that listeners frequently believe major acts remain homogeneous in their lyrics and thus, their authenticity is consistently questioned by fans concerned about commercialization. They argue that indies are alternatively allowed more creative freedom but require validation of authenticity from listeners that usually come from meaningful social, political, and cultural messages that relate to the respondents' social locations of race, class, and gender. As discussed more fully below, both males and females emphasize the progressive nature of race and class themes found within independent hip-hop. A number of female and LGBTQA respondents suggest that, although there are notable exceptions, problems of the objectification of women and heteronormativity are common within indie hip-hop and tend to be produced by straight working-class 
men of color, which challenges traditional post-golden era narratives of authenticity.

\section{Record Label Matters?}

Forman (2000) argues that the formation of indie labels has historically been as a response to the economic competition with major labels and thus forms a large part of artists' identity. Nearly $75 \%$ (thirty-four) of respondents similarly state that one of the most important distinctions between acts is still their record label status. David states that "mainstream artists are financially backed by large record companies." On the other hand, indies "produce everything without the financial backing of a major record label." Instead, they are signed by smaller labels or sometimes not signed at all. Felipe argues that in many instances they are "left to fund their own music, tours, and projects." Kathy emphasizes that they are usually relegated to the underground or peripheries of hip-hop culture. Their access to resources remains limited and their public exposure is generally centered on a particular genre, fan base, or geographical location.

Both musicians interviewed note the vast economic disparity between the two industries. Anthony Colon, founder and CEO of AGC Productions, writes "the big deal and the locals are two different worlds." He recapitulates David's sentiments, stating that they remain relatively local and small scale as they are pushing to make a name for themselves in the underground market. Carlos, an unsigned rapper from San Diego who goes by the name Mac Dirrty, adds that "I'm independent cause I pay for all my own shit in music. I pay for the studio time [and] rip the beats...I even [have] homies making beats for me now." He notes that "the majors can afford to buy big name producers such as Dr. Dre for a million dollars...I have my roommates rip me beats for a couple hundred dollars and I'm only making .005 cents a stream." Like Anthony, he details the large gap in the economic disparity between the mainstream and independents. Carlos recalls having to navigate between working his full-time job to make ends meet and making music in his spare time, which he believes is a very different experience than musicians who are economically supported by large corporations for a majority of their careers. For both listeners and rappers themselves, record label status remains salient (Fig. 4.1). 


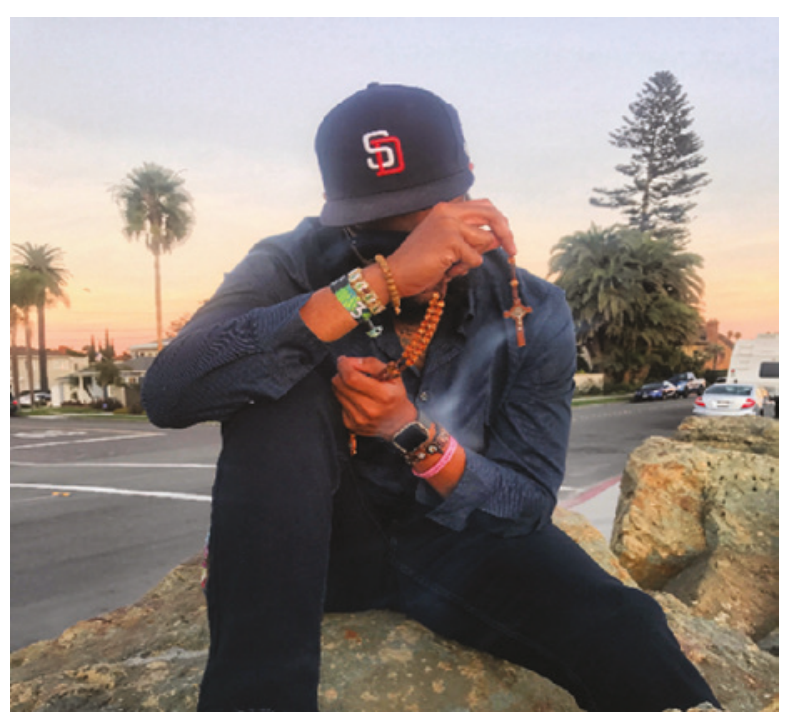

Fig. 4.1 Carlos (Stagename: Mac Dirrty) (Credit Carlos Sanchez)

\section{What's Bebind the Label?}

A second dominant theme regarding the distinction between major and indie hip-hop today is the importance of creative musical freedom, which about $75 \%$ (thirty-five) of respondents mentioned in their interviews. Hibbett (2005) points out that simply looking at major record label status is a "benign" definition. In the case of indie rock, it is marked by the awareness of a new aesthetic in which punks created a movement based on the audiences' desire for social differentiation. In the 1970s, they created this desire by pushing a "do-it-yourself" ethic focused on messages less regulated than mainstream radio (Strachan 2007). David states that:

Often major record companies [today] will make [an] artist portray a certain image for marketing, which can go against the artists' beliefs. Independent artists usually have no influence in regards to a marketing image, and they're free to be who they want to be.

David highlights that limitations on creative freedom can hinder the musicians' ability to freely make music. In addition, Kathy differentiates 
major and independent hip-hop by stating that musicians in the mainstream have less control because companies view them primarily as an "avenue for sales." She alternatively mentions that indies primarily operate in the underground and are not as highly swayed by the influence of large corporations.

Both rappers Anthony and Carlos emphasize the importance of maintaining creative and economic control of their own music. As Moore (2007) argues, the act of producing music and media that is relatively autonomous from corporate industry motivates smaller acts to create an alternative field of cultural production that is not reliant upon big businesses. While Anthony and Carlos remain relatively local and underground, they understand the benefits of keeping middlemen out and controlling the day-to-day operations of their music and their label. As Anthony vehemently states, "I cut out every middle man during this project! I did not need a promoter or talent scout. My company supports only one artist, which is me."

\section{What Is "Real" Hip-Hop?}

The question of authenticity remains a recurring topic among 50\% (twenty-three) of the interviewees. They argue that authenticity, or the negotiated validation by both artists and listeners, is important in determining if the performers' persona is "genuine or accurate in its depiction." Respondents highlight that major label acts are limited in their messages and their authenticity is frequently challenged, while independent musicians have more creative freedom but need to obtain their authenticity from fans.

About 70\% (thirty-one) of listeners believe that the majors are highly constrained in their creative freedom. The immersion of large corporations in hip-hop has decreased lyrical and musical diversity due to the pressure to be financially successful (Fox 2004; Myer and Kleck 2007). Liz writes: "mainstream is music that is heard repeatedly on the radio. It's music that the public wants to hear." Carlos, an unsigned musician himself, calls this type of music "bubble gum [and] sing-along rap" where the "lyrics are shallow and the beats are poppy." Interviewees such as Samantha and Jackie add that hip-hop generally follows formulaic trends. For Jackie, these trends are repeated messages of "sex, money, drugs, and violence" that appeal to the broader audience. The idea of sex is prominent in a male-oriented perspective that treats women as "sexual 
objects," in which Samantha states she "did not even notice growing up." They both note that the obsession with money, drugs, and violence becomes the stereotypical image for rappers as it preys on "the desires of urban Americans who want to be successful themselves."

About $40 \%$ (twenty) of respondents believe that social and political messages addressing problems in contemporary American society only appear during times of social distress. Liz states that generally large label musicians do not "speak much on social or political issues." Andrew supports her statement by arguing:

The main messages on the [radio] being shared are controlled by whatever the industry wants you to hear. The industry regulates what is to be heard or not. These are the reasons we don't hear music on police brutality or racial superiority on the radio. Mainstream hip-hop is regulating people only to what is on the radio as if that is the only music being made.

Andrew's responses indicate that messages addressing the issues of urban communities are generally ignored, with much of the music producing messages concordant with the dominant culture and status quo. Sebastian adds that the majors generally do not reflect on social issues unless it is during a period of social crises. He believes that they do not try to rap about controversial issues, but notes that political and social messages may appear if they reflect the popular sentiments of American society at a particular time. He cites the song "FDT (Fuck Donald Trump)" by YG and Nipsey Hussle as a song that represents mainstream political issues during the 2016 presidential elections. He concludes that companies would only approve these messages if it were financially beneficial for them in the long run; otherwise, they are often dropped from publicized album releases. Sierra recaps these sentiments by stating that major acts are a reflection of "what the people specifically may 'want' to hear at a certain time and what sells rather than substance."

$65 \%$ (thirty) of interviews indicate that corporate control puts into question the legitimacy of a rapper's persona and musical content. Hesmondhalgh (1999) points out that hip-hop faces similar problems to rock n' roll with the notion of "sell outs, or the pressures towards professionalization and partnership." This is particularly problematic for acts that garnered attention in the underground and were later signed by the majors to address issues of dispersion and diffusion (Jones 2002). For example, Christina thinks "the industry is a bit censored because there 
are only so many things you can put out in popular music...because obviously you give up something, especially if you were political before." Shawn reiterates Christina's sentiments, claiming that many rappers are questioned for selling out, which for him means changing their image and music to appease labels and appeal to a wider array of audiences. He writes, "a big part of hip-hop is the message the music sends, and that's what a lot of listeners are in it for. So I've had people tell me they don't like mainstream because the artists are 'sell outs'."

Even indies themselves corroborate the notion of selling out. Anthony, founder and CEO of AGC Productions, speaks of his fear of large corporations when he says, "yeah, I've turned down opportunities because I was afraid of people taking my ideas or trying to change me." He continues to speak of his love for the music and being afraid that his message and style would be altered by companies seeking to capitalize on his brand name and ideas. This is reinforced during his album release party when he reminds his friends that he hosts his own shows on his own terms without sponsors. More importantly for him, he argues that “[I] don't have to kiss anyone's ass...that's why this whole project is independent, all the way down bro."

In addition, roughly $50 \%$ (twenty-four) of interviews mention that musicians who choose to remain independent generally have a different "vibe" to their music. The vibe tends to focus on socially conscious messages that attempt to distance itself from mass commercialization (Rose 2008). As performers Aesop Rock and Rob Sonic state, "as long as we can do what we want to do...then [independent] is the move" (The NE Hip-Hop 2015). In this alternative underground space, there is more room to critically challenge the conventional norms of mainstream hiphop culture (Morgan and Bennett 2011; Harrison 2006). Listeners claim that indies focus on lyrical and musical innovation not constrained by corporate executives. Crystal writes, "[indie artists'] creativity is on another level. They are not withheld so much and you feel that passion in their lyrics. You can tell that they put in the effort and are trying to reach from within to get a message out [to the public]." Janine adds that they can freely delve deeper into issues because they are not constrained by a slew of production and management teams making decisions for them. More importantly, Pathik notes that these messages and issues are visibly important to them because they willingly choose to rap about them. 
Alyssa, a full-time student and part-time server at a restaurant, writes of her first experiences with Immortal Technique's music. She recalls the first time she heard the track "Dance with the Devil":

I was 15 and after school every day I would hang out with my boyfriend. We would drink at this park in my apartment complex. It was raining so we were sitting in an obstacle course near the slides under a blanket and he showed me this song. I was...amazed. I had never heard hip-hip that actually had a message besides 'fuck bitches, get money.' Even though that particular song wasn't something I can relate to it was something that people don't like to talk about, but a lot of underground artists rap about... the issues that people ignore or don't care about enough. That's when I first really got into hip-hop.

While she points out that the song was not something she experienced herself, she finds that the meaningful images it portrayed were immediately felt. Alyssa expresses that these creative and political messages would be much harder to find with major acts that are heavily constrained in their freedom of speech.

$50 \%$ (twenty-three) of interviews indicate that much of indie culture hinges on the perceived authenticity of musicians. While the notion of authenticity is constantly negotiated between performers and listeners (Harkness 2012), many fans believe authenticity to be real and measurable. Respondents similarly state that major acts have to appeal to the masses and thus are less focused on socially and politically conscious messages and musical innovation, but rather on sales and profit. Conversely, independents have greater ability to make music freely because they are appealing to smaller, niche markets. But these messages need to be positively received by the hip-hop community in order for them to build a fan base. Listeners need to validate their music in order for them to be perceived as authentic.

One such means of validation is to reconnect with hip-hop's roots. Matt writes that:

I began listening to older hip-hop and not just the mainstream hip-hop singles on the radio. It was a form of music that was different and it featured a lot of storytelling and personal narrative(s) that reflected everyday experiences that were more relevant to the general population than just money, women, and cars. It talked about education, working-class issues, racism, politics, and the influence of money. 
He adds that much of the culture today has been far removed from its origins in the streets of New York where issues of racism and classism were discussed. Samantha shares that independents are much more similar to the roots of how hip-hop used to be. She believes that you can feel the emotions and that it comes from a different place, predominantly before hiphop was commodified and globalized by whites. Interviewee Liz believes that this is particularly important because the current generation is less informed on social and political issues and becoming more entrenched with individualism. My interviews ultimately show that fans believe authenticity still needs to be gained through the artists' messages. As Sasha writes, "independent hip-hop is more meaningful, personal, and [more about the] history attached to peoples' lives.”

\section{What's Race, Class, and Gender Got to Do with It?}

Respondents frequently find a more intimate understanding of social locations with indie artists that operate outside of the mainstream market. In particular, they mention the importance of lyrics connecting with their life experiences concordant with their social locations of race, class, and gender. But interviewees state that while musicians frequently address issues of race and class critically, they often mirror broader hip-hop culture in regards to the objectification of women and heteronormativity.

First, nearly $60 \%$ (twenty-six) of listeners, overwhelmingly the working-class interviewees of color, feel independents portray similar everyday life struggles as themselves. Folami (2007) states that hip-hop provides a commentary on social life, particularly given the invisibility and marginality of poor racial minorities in American society. Interviewees similarly mention that majors depict an image of being economically successful, which creates a disjuncture with many listeners barely getting by in America. Pathik, a working-class Indian, recalls the first time he heard Strange Records' Tech N9ne:

It was my senior year in high school and I was really feeling down in the dumps. I was being called a dumb-fool if I believed I could become something in my life. Two of my neighbors flunked out of college, while another dropped out because he was in too much debt. Inside I was superhappy to have been accepted to college, and it was always my dream. I wanted to go out into the world, get a college degree, and become 
something so that my parents wouldn't have to work anymore. That's when I first listened to the song "Mental Giant" by Tech N9ne. He wrote: 'Even though I'm 5 foot 8 inches and 195 pounds I'm looking down on your niggaz, so tall I can't even hear any of the sound you deliver.'

He claims that these types of songs better address class issues in the USA than the messages delivered in the mainstream because the rappers face similar struggles as their working-class listeners. Pathik emphasizes the song "Mental Giant" to represent the hardships he has endured just making it to college. He notes that he can relate his experiences with Tech N9ne's because of the struggle that he endured to create a successful career in the hip-hop game.

Issues of race remain particularly important for black and Latino interviewees. Scholars (Forman 2010; Gosa 2010) argue that Obama's recent administration has spurred multiple performers and fans to address issues of race and class in a post-Civil Rights America (Forman 2010). While respondents construct their racial and ethnic identity differently, many connect their racial and ethnic background to hip-hop through a similar struggle against a legacy of imperialism and their personal experiences of racism. Sebastian highlights music by Viper Records' Immortal Technique, particularly the song entitled "Poverty of Philosophy":

Immortal Technique speaks about the inequality there is in the world between the rich and the poor and the history that made this evident. [But] he speaks about how the European nations during colonial imperialism used the 'new world' as a way to only export resources and did not really care about the effects on the indigenous people. He speaks about how classism is as an important issue to deal with as racism and that people at the bottom should stick together and not go against each other in order to help everyone [to] rise together and move forward.

Alternatively, white and Asian interviewees did not highlight their racial and ethnic identity and the importance of the opposition to white supremacy within independent hip-hop as frequently as black and Latino listeners. Asians in particular focus on the lack of representation in the culture's community, but emphasize their class struggle to recognize their shared marginalized position in society. Nonetheless, respondents assert that compared to the majors, independent rappers better address their personal social locations regarding race and class. 
Further, interviews highlight the importance of race and class inequality in the music industry itself. Myer and Kleck (2007) argue that white males in the three major record labels are overrepresented in managerial and ownership positions. For instance, Angelica describes the hip-hop industry as controlled by "white men." She claims that those in positions of power at record companies control the industry and seek to turn it into a profitable business. As she states,

What started out as an outlet to rebel against mistreatment [and] a voice to fight back, has now turned and focused on the number of albums sold and tour dates. Hip-hop is directly and almost always linked with blacks. The difference between whites and blacks in the industry is the way they are portrayed in the media. Blacks are talked down upon, disregarded, and exploited...or they are seen as aggressive and angry. Whites are always talked about so respectfully, gracefully and praised for every little good thing they do.

These sentiments mirror other respondents, as they argue that white elites often control the messages presented in the music that black rappers create. While many minorities, particularly black entrepreneurs such as Dr. Dre, Jay-Z, Master P, Puff Daddy, Queen Latifah, and Russell Simmons, have been able to make a dent in white domination and the appropriation of hip-hop culture (Basu and Werbner 2001; Sköld and Rehn 2007), there remains problems of racial inequality within the music industry. Moreover, black musicians often reproduce white ideology despite the detrimental effects it may have on their own community. As a result, interviewees believe that various messages presented by major acts do not represent their social experiences but instead represent broad generalizations and stereotypes about low-income urban communities of color.

Second, listeners believe independent musicians in the post-golden era remained sexist, heteronormative, and homophobic in their lyrics and personas despite their progressive views on race and class relations. This is due to indie hip-hop still being composed predominantly of straight working-class men of color who most commonly make claims of authenticity within hip-hop culture. Oware (2014) makes a similar argument, stating that messages of violence and misogyny are still present in the underground despite claims of being rebellious and socially conscious. Of the twenty-two female and LGBTQA interviewees, nearly $70 \%$ (fifteen) mention female and LGBTQA indie artists that are more 
attentive to issues of gender and sexuality in their responses. They contend that hip-hop still has the potential to reproduce unequal gender relations, particularly for young black girls navigating their sexuality (Alim et al. 2010; Asante 2008; Gupta-Carlson 2010; Pough 2004). Amanda states, "Even though I listen to it and enjoy it, I still recognize that a lot of hip-hop reinforces sexism and is beyond disrespectful toward women." Samantha adds that often these representations of women are "as sex symbols, as submissive, as a commodity" viewed through a heteronormative male lens that emphasizes hegemonic masculinity (Alim et al. 2010; Hunter 2011). More importantly for Angelica, they are "not just any women, [but] usually black and Latina women." For female respondents in particular, they argue that indie culture is still an industry predominated and controlled by heterosexual men who parrot misogynistic, violent, and materialist lyrics of their mainstream counterparts.

They did report instances of socially conscious indie rappers being more attentive to the issues of gender and sexuality, which shifts the boundaries of authenticity to address increased representation by women and LBTQA members. Kathy writes that Macklemore LLC's Macklemore and Ryan Lewis have numerous songs on race, class, and gender inequality. The song "Same Love" openly addresses issues of sexuality and advocates for gay marriage. She notes that "even though I'm straight, I hated how LGBT groups were being judged and hated just because they liked the same sex rather than the opposite sex... they're still human beings." Following the legacy of many socially conscious rappers, Sierra argues that artists and listeners can "take this norm of dehumanizing women in hip-hop music out of society... and [we can] implement a more accepting mindset."

Similarly, LGBTQ rappers have been able to create niche spaces in hip-hop's underground. As Christina states, "LGBTQ rappers are setting a new trend in the hip-hop community of defying traditional stereotypes about rappers." Mykki Blanco, an independent transgender rapper on New York-based label UNO, has obtained buzz in the hip-hop world. While his songs are outwardly vulgar, his lyrics bring attention to issues of the LGBTQ community and he gives rappers a cultural space to navigate their sexual identity (Stern 2016). For example, Mykki Blanco has publicly addressed the problem of HIV and the stigmas attached with coming out. Mykki Blanco states (Reynolds 2015): 
I've been HIV-Positive since 2011, my entire career. Fuck stigma and hiding in the dark, this is my real life. I'm healthy... I've toured the world 3 times but I've been living in the dark, it's time to actually be as punk as I say I am... No more living a lie. HAPPY PRIDE.

Other acts have also gained traction in the LGBTQ hip-hop community. After Pitchfork's cosign (Raymer 2013), Mishka Records' queer rapper Cakes da Killa has obtained more mainstream success as part of the LGBTQ hip-hop genre with his album The Eulogy. While Queen Pen was originally seen as the first lesbian rapper in 1997, a new genre of lesbian artists such as "Kelow, Elektrik, Envy, MC Angel, RoxXxan, Yo Majesty, and God-des \& She" is gaining popular support (Schwartzberg 2014). Rainbow Noise has also cultivated a movement under the premise that labels need to highlight LGBTQ talent in the hip-hop community (Carter 2014).

By reflecting on the intersections of race, class, and gender within their lyrics, independent musicians can more freely express their life experiences and ideas with audiences that understand, relate, or sympathize with marginalized social locations to promote oppositional consciousness (Harkness 2012; Jeffries 2011; Mansbridge and Morris 2001). Yet, while respondents note that indie culture is more inclined to include messages critical of the relations of dominations with regard to race, class, and gender than major musicians, they acknowledge exceptions. They often include the caveat that large label acts can present meaningful messages, while indie rappers may not be politically or socially conscious at all. Felipe notes that indie hip-hop "doesn't have to have a 'meaningful message' because I've heard underground artists rap about girls and money." He goes on to state that many indies merely reflect the ideologies of mainstream hip-hop culture and broader American culture as a whole. Like other informants, he suggests that the distinction between major and indie is not black and white but blurry.

\section{The Blurry Lines Between the Mainstream and Indies}

While interviews suggest that the division between major and indie status remains salient, responses often allude to the fact that many acts today navigate a "mixed space" by which performers attempt to retain economic and creative freedom while still attempting to become 
financially successful. Listeners do not view major and indie hip-hop as mutually exclusive or opposing types of music. Instead, the distinctions between them are fluid and constantly changing, particularly in two ways. They note that independent acts are frequently pulled and pushed toward large record labels. Respondents state that numerous rappers they listen to try to remain indie. But because of the need to survive in the hip-hop industry, they believe numerous musicians have to navigate the borders of major and indie. Also, interviewees believe that the indie movement has changed over time. They frequently note the recent period of commodification by large corporations, as well as resistance by smaller businesses utilizing advances in technology to enter the market without the support of the majors. Nonetheless, results indicate that both the mainstream and indie markets remain complexly intertwined with one another in various ways such as affiliating with major companies to utilize their marketing and distribution channels.

\section{Mixed Space Between the Majors and Indies}

The blurred lines between the majors and indies exist due to frequent pull and push factors, which is cited by roughly 25\% (thirteen) of respondents. On the one hand, interviewees indicate that many acts get pulled by the majors as they become increasingly popular. Karubian (2009) argues that big labels sign fewer acts today and instead focus on signing established independent acts that have already gained visibility in the underground and are looking to break into the mainstream. Pathik reinforces this point by pointing out that nearly "every artist starts off underground regardless...like Wiz Khalifa or 50 Cent before they came up." Souphakone makes a similar observation with Wiz, stating that "when Wiz Khalifa was an independent artist...hella dope. I respected his lyrics, respected the grind, even the trademark I'm high as fuck laugh." But Souphakone continues to state that certain performers get enough buzz that they eventually become popular acts that get pulled into the majors.

Alyssa states: "I feel like Logic has changed since he has gotten bigger even though he claims he hasn't." Logic, originally signed to Visionary Music Group, proclaimed on his mixtapes that he would remain independent. But in 2013, his mixtapes were approaching one million downloads and he eventually signed to Def Jam Recordings (Paine 2013). 
David similarly uses the example of Anderson Paak (formerly known as Breezy Lovejoy), "who worked with a lot of well-known emcees and producers...he's now on Aftermath." As Anderson Paak, he initially released an album entitled Venice on Steel Wool Entertainment. After obtaining more popularity in 2015 with an appearance on Dr. Dre's Compton, he eventually signed with Aftermath Entertainment, a subsidiary of Universal Music Group's Interscope Records (Peters and Martin 2016).

On the other hand, respondents point out that many musicians get pushed into large corporations due to the need for financial security and resources. Various artists may treat the indie and underground scene as a "waiting station or the minor leagues" until they achieve more popularity and sign lucrative contracts with major labels (Oware 2014). As Julian states, numerous rappers utilize the underground market to gain popularity with the intention of obtaining wealth and fame. He states, "Well I think what happens is that they get a taste of all that fame and fortune, and it begins to overwhelm them." Julian cites rapper Chief Keef as a primary example as he gained popularity in Chicago's underground and eventually signed a 6 million dollar deal with Interscope. The contract included $\$ 440,000$ in advances and the creation of his own imprint called Glory Boyz Entertainment (Markman 2013). Carlos similarly speaks of Mac Miller leaving Pittsburg indie label Rostrum Records for Warner Bros. Records. Rostrum obtained success through a strong digital presence and investing heavily in touring (Ostrove 2014). But Mac Miller joined Warner Bros. Records for a 10 million dollar signing deal and the creation of his own subsidiary label REMember Music. In both cases, the artists left smaller companies in exchange for financial advances and resources. Drake (2015), a Complex.com writer, argues that many musicians who reach a high level of popularity but lack capital may also be pushed into the majors to meet demand. He cites examples of Young Thug and Bobby Shmurda as acts that likely needed to sign deals with large companies who own a vast amount of financial capital. This is likely to push them into the mainstream, despite less favorable terms on their contract due to the need for resources (Karubian 2009).

With the frequent pull and push factors, listeners state that they are frequently left to determine if acts who shift spaces are still considered "authentic." For many listeners, it is becoming harder and harder to determine what is truly independent (Andrews 2006; Hess 2012; Oware 2014). Souphakone writes that he "doesn't listen 
to [Wiz Khalifa] like that anymore" because his lyrics and persona changed. Pathik adds that he understands that being signed to a large corporation can change the music because they are now controlled by outside parties with different interests. Yet, listeners also argue that rappers who sign to the majors do not always change their message. Felipe and Julian add that some rap legends like Nas and Common "came up as underground hip-hop but they've also blown up so big that they have tasted the fame and money, but I think they still stay true to what they were all about when they first came up." Academics and respondents suggest that there is a gray area between major and independent that many acts navigate as a result of the constant pull and push factors within hip-hop.

In addition, about $40 \%$ (eighteen) of listeners state that numerous musicians navigate between being major and independent. Harrison (2006) argues that underground acts, whose popularity largely consists of friends, family, and other associates, attempt to extend their fan base outside their circle. Once they do, they must decide throughout their careers whether to be unsigned, sign with or create an independent company, or sign with a big mainstream corporation. For example, some acts began their careers signing with a large label but have since dropped their label to obtain successful careers as indie artists (Hess 2012; Oware 2014). Felipe states that "I see artists like Del who are better in the indie circuit." Del the Funky Homosapien had released two commercially successful albums in the early 1990s with Elektra, a subsidiary of Warner Bros. Music. In 1997, Elektra dropped him from their label a month before the release of Future Development. He later signed with Hieroglyphics Imperium Recordings and released the album in 2002. Del the Funky Homosapien has remained independent and voiced his discontent with Elektra. He has since released nine studio albums and signed to indie label Definitive Jux in 2007 (Bechtel 2016; Ostrove 2014).

Julian points to Killer Mike as a successful act who also did better without a big contract. Killer Mike released Monster in 2003 under Sony Records' Columbia. With singles such as Akshon (Yeah!) and A.D.I.D.A.S., Killer Mike reached Billboard's Hot 100. But following his release he had a fallout with Outkast and Sony Records and was not able to release I Pledge Allegiance to the Grind until 2006 under his self-formed label Grind Time Official (Markman 2011). He has since released three solo albums and collaborated with El-P to form Run the Jewels on Universal subsidiary Fool's Gold. 
Respondents also state that many musicians navigate between major and independent status as they try to remain culturally relevant and financially profitable. For some, this means moving between the major and indie circuit as their careers progress. Julian recalls MURS' move to Strange Records and calling his album "straight fire." In 2008, MURS garnered attention as he was set to release MURS for President on Warner Bros. Records. He had previously been linked to the indie hip-hop scene, but stated that he "had a bigger budget to work with... [could] get any names [he] wanted....and the album was mixed better" (Ollison 2008). After his album's debut, Warner Bros. Records released MURS over a "difference in opinion" (Cooper 2009). He has since signed with Tech N9ne's Strange Records and then released Have A Nice Life in 2015 to positive reviews (Moore 2015).

Rappers such as Lupe Fiasco have voiced their discontent with their contracts. Alyssa mentions that "I've always considered Lupe Fiasco to be major because I heard him on the radio." In fact, Lupe Fiasco has remained on a large record company for a majority of his career despite his tensions with Warner Bros. Music's Atlantic. The release of 2011's Lasers was met with much controversy. Atlantic executives felt the album needed guest stars and star-potential hits, which caused Lupe to alter the production of his album (Frazier 2010). While he ultimately worked with them to release Lasers, he later voiced his distaste for the work and even offered to destroy any physical copies of the record that his fans purchased (Ahmed 2011). Alyssa notes that "of all his albums, Lasers was by far the worst because of the production." Lupe himself has stated that he wants off Atlantic Records due to being treated as a "third class citizen" because he did not sign a 360-degree contract with them. These contracts are preferred because they allow companies to extract profits from various aspects of the signees' revenue stream to account for the downturn in record sales in the digital era, which was generally not part of traditional recording deals. These aspects can include any aspect of their career and hence the term 360 degrees, such as merchandising, touring, and commercial endorsements (Marshall 2013; Stahl and Meier 2012). More recently, Lupe departed from Atlantic and signed with Nashville-based entertainment company Thirty Tigers.

Independent labels themselves also face the same dilemma as they attempt to earn profits, obtain success, and expand. Interviewees Felix and Julian recall how small companies such as Death Row and Bad Boy were bought out or merged with big labels in the 1990s (Knab 2004). 
As Warner Bros. Music's owner Len Blavatnik, Universal CEO Lucian Grainge, and Sony's Music Chief Doug Morris state (Greenburg 2015), "the majors have figured out that it's smarter to bully their way into companies seeking to take their lunch." Respondents also cite the process of musicians having to sign with the majors when their indie labels are bought out. As David states, "Ironically the same indie emcees I used to listen to are now active in the mainstream market. Mos Def [is] not only well known in mainstream music and movies... [but now is] signed." Arianna adds that Mos Def still has "inspiring and thoughtful message[s], but navigate[s] between major and indie throughout the years." In Mos Def's case, he was originally signed with Rawkus Records. They gained notoriety as a premier underground hip-hop label in the 1990s. But in the early 2000s Rawkus Records folded and was bought out by Interscope (Greene 2015). Since the merger, Mos Def has verbally sparred with the company until he fulfilled his last contractual album True Magic in 2006 (Baker 2014). He then signed to independent label Downtown's roster and released The Ecstatic in 2009. Ultimately, these cases illustrate the mixed space between major and indie by which many musicians navigate throughout their careers.

\section{The Changing Nature of Hip-Hop's Indie Movement}

Nearly 50\% (twenty-two) of respondents describe how independent hiphop has evolved and changed in numerous ways over the years. Older interviewees point to the prominence of indie rappers in the early 2000 s. Like punk rock (Hesmondalgh 1999), independent hip-hop has seen periods of commodification and resistance. But as Lopes (1992) points out, these periods are specific to the industry. During its roots in the 1970s, New York hip-hop focused on performances in the streets and was concerned with social and political issues such as poverty and racism. As the culture became more popular in the late 1980s and early 1990s, the golden era saw the mass commodification of numerous acts by large corporations hoping to gain financial success. Following the decline of the golden era in the late 1990s and early 2000s came a period of underground and indie hip-hop resisting major label corporatization. For example, David writes that "ten years ago I used to pay attention to see who's either mainstream or independent. There is a lot of pride with music from an independent artist because everything was created from 
the artist." Jayson similarly states that "in the 2000s I did listen to a lot of underground acts because it was pushed hard back in the day." Both respondents indicate that the late 1990s and early 2000s were periods marked by the rise of an indie movement. Older interviewees recall that independents utilized an "anti-mainstream" approach that appropriated street culture and the rejection of corporate America in music. Jayson cites acts such as "Living Legends, Grouch and Eligh, Slug, Murs, and Immortal Technique back in the day at Rock the Bells and other HipHop Festivals" as highly influential to the movement.

In response to the rise of a revitalized indie movement in the early 2000s, major labels attempted to remain relevant by creating 360 -degree contracts. These contracts extract profits from various aspects of the signee's revenue stream such as merchandising, touring, and commercial endorsements (Marshall 2013; Stahl and Meier 2012), and utilize the new modes of musical production to offset declining record sales (Leyshon et al. 2005) (see Chapter 3). Fox (2004) also argues that large companies attempted to control online music through the creation of copyright-protected files and lawsuits against the providers of free music. As Christina writes, "popular discourse is tightly controlled by labels and corporations like iTunes." She argues that companies re-secured the modes of musical production by restricting illegal downloads and investing heavily in online models such as iTunes, Spotify, Pandora, and Shazam. In 2014, Warner Music Group bought 5\% of a then bankrupt SoundCloud, while Universal owned rights to Beats by Dre and obtained 13\% of Apple stock. Greenburg (2015) adds that the major labels-Warner, Universal, and Sony-owned 10-20\% of the entertainment startups in the digital space in 2015 . As a result, listeners contend that the indie culture of the early 2000 s declined. Jayson further elaborates: "I did listen to a lot of underground because I hate the radio...but it's just different now." David clarifies by stating that "back then a lot of independent artists would attack mainstream artists for selling out, being fake and manufactured by the record label. Because of [changes to] the industry, I feel that things are different now." He argues that after re-commodification by large corporations the indie movement declined and forced many rappers to become mainstream.

Yet, slightly over $50 \%$ (twenty-four) of respondents of all ages argue that current indie culture has been able to better obtain commercial success utilizing advances in technology, such as online distribution and social media outlets, without the support of large corporations (Karubian 
2009). Jones (2002) asserts that the rise of the phonograph and radio in the first quarter of the twentieth century changed the landscape of music. Up until the 1970s, the recording industry was able to monopolize access to recording studios and other means of distribution. By the early 1990s, the music industry shifted again due to the prevalence of the Internet's music distribution capabilities. Despite major labels' attempts to control the Internet, independent acts have been able to secure the means of musical production and thus the marketplace has shifted to a more democratic organizational system (McLeod 2005). As Andrews (2006) argues, "the internet and file-sharing systems have allowed for more accessibility and better distribution for smaller labels and imprints." Musicians Aesop Rock and Rob Sonic concur, stating that "technology open [ed] up different doors and avenues [for hip-hop culture]" (The NE Hip-Hop 2015). Rapper Brother Ali adds that these avenues were not even fathomable in the late 1990s (Hip Hop Since 1987 TV 2013).

Interviewees such as Carlos share similar sentiments about technological advancements. He recalls recording music on blank tapes off the radio: "I would wait for songs I liked and I would run to record them when they were about to start." He notes that major radio stations controlled the music he heard growing up, but interviewee Jessica N. remembers the rise of iPods and MP3 formats in making music consumption easier to access for both producer and consumer. David adds that the rise of "YouTube has given [artists] the ability to put music out there much easier." Nielson's study (Burgess 2012) shows that “64\% of teenagers now listen to music through YouTube than through any other source." More recently Jessica F., a 21-year-old college student, points to SoundCloud as a primary medium of music consumption among the people she knows. SoundCloud acts face a low barrier to entry, with an understanding that becoming viral is highly dependent upon direct fan contact. As a result, the recent movement of "SoundCloud rap" has become more popular among performers and fans today (Caramanica 2017).

Social media web sites have spurred on the popularity of acts without the expensive traditional means of promotion such as Street Teams and fliers. Christina notes that "independent hip-hop had an opportunity with Myspace and other internet mediums." Rapper Talib Kweli (Greene 2015 ) shares similar views, writing that "Myspace is what got me online [in] a real way." Other Web sites such as Facebook, Instagram, Snapchat, and Twitter have given musicians a platform to release and promote their music. In particular, these mediums allow numerous acts to enter the 
eyes and ears of listeners easier and faster. As Jayson argues, "the internet plays a big role now...you can get fame easier if you put yourself out there. People talk about you and share your music through the world wide web... and you're sitting in the comforts of your own home and not going out there to promote." David states that this ultimately allows many more musicians to gain mainstream popularity.

Respondents frequently referred to rappers such as Tech N9ne and Macklemore and Ryan Lewis, who have demonstrated how small homegrown labels can promote successful acts through the use of technology and social media. More recently, unsigned performer Chance the Rapper has released music on free platforms such as Datpiff and SoundCloud, focusing on a strong relationship with listeners using social media to achieve monumental success. Interviewee and unsigned act Carlos states that "I see artists like Tech N9ne as pioneers who changed the game." Tech N9ne, a hip-hop veteran, has chosen to remain on Strange Records since the 1990s. He attributes his success to building a strong brand name characterized by strong shows with a solid fan base (Nguyen 2015a). This is aided by a strong online presence focused on "stay[ing] within an arms-length of his fans" (Biondo 2012). Strange Music's Twitter and Facebook pages remain active and full of cosigns from other celebrities who endorse their brand. Andrew, a 21-year-old college student, additionally points to Macklemore and Ryan Lewis as trendsetters in hip-hop today. Macklemore LLC's Macklemore and Ryan Lewis have become successful through similar promotional techniques to Tech N9ne. Smith (2012) cites Macklemore's success to savvy social media marketing, a socially conscious message, a DIY stance, and a unique personal image. Like Tech N9ne, a streamlined and personal relationship with fans decreases the need of A\&R from major labels (Drake 2015). Andrew also cites more recent rappers such as Migos and Fetty Wap, who have joined independent label 300 Entertainment. Under Lyor Cohen and Todd Moscowitz's vision, 300 Entertainment gives local stars an opportunity to become successful through a strong focus on analytics (Nguyen 2015b). Utilizing data, Quality Control Music's "Coach" and "Pee" were given an innovative deal with 300 Entertainment for distribution and marketing. Their successful model includes hiring their own radio and promotion staff, personally publishing and managing venues, and hiring in-demand producers and engineers (Peisner 2015). As such, Strange Records, Macklemore LLC, and 300 Entertainment all push for a strong online presence with an attuned ear to the digital 
age (Drake 2015). Ultimately, the new wave of indie hip-hop utilizes the technological advancements made by major corporations to resist corporatization and produce music outside of the traditional modes of distribution.

Further, the most recent wave of independent artists and labels has remained highly intertwined with major record companies as they continue to coexist in the music industry. Suhr's (2011) finds that recent shifts in the music industry show major and independent labels converging despite their consistently changing relations of tension and compatibility. For instance, many acts signed to indie labels maximize sales through the process of affiliating with large corporations (Knab 2004). They reduce the risk of bankruptcy with independent distributors by instead using a major label distribution system, which usually has the backing of a parent company such as Warner Bros. or Universal. Large corporations see the value in distribution because they still obtain a significant portion of the profits despite not owning the company (Marshall 2013).

Interviewees Julian and Felix recall several popular labels adopting this model in the 1990s. In 1998, Cash Money Records signed a widely publicized blockbuster 30 million dollar distribution deal with Universal (XXL Staff 2008). Although this received considerable attention from fans, many alleged indie labels of the era such as Def Jam, Roc-A-Fella, Bad Boy, and No Limit were also subsidiaries of large corporations. While the idea of affiliating is not new, it has become more frequent with self-proclaimed "indie-DIY" artists today, thus again challenging the significance of the term indie.

Jayson similarly remembers more recently that even Rhymesayers Entertainment, along with one of its flagship acts Brother Ali, signed a distribution deal with Alternative Distribution Alliance (ADA), Warner Bros. Music Groups' independent distributor, to expand their company. Matt similarly states that "I don't really like Macklemore and Ryan Lewis because I question their music." He elaborates that "Sometimes I feel their message but other times they put out pop shit." Matt's concerns were shared by others in the hip-hop community as Macklemore and Ryan Lewis fell under attack by National Public Radio (NPR) and Rap Radar for falsely calling themselves independent (Smith 2013). As Figure 4 illustrates, Macklemore and Ryan Lewis were also distributed and promoted by ADA (Fig. 4.2).

In a 2012 interview, Macklemore stated that he was not opposed to major corporations but merely acting in his own best career interests 
(Bootleg Kev 2012). While there has been resistance to distribution deals, for example by small British labels (Gottfried 2014), indie companies have become less "indie" because of their need for capital from major corporations to keep up with demand.

Publicity and promotion also play a large part of the music industry in the digital age. Smaller labels often need to hire professional teams to market and license their songs to compete (Andrews 2006). Both of the two independent artists interviewed acknowledged the importance of successful marketing, which is easier to obtain with the help the financial resources of large companies. One method they find useful is online streaming playlist placement with corporations such as Spotify or YouTube. While this does not necessarily increase profits as the average artist only gets paid .006 to .008 cents per stream on Spotify (Sehgal 2018), it provides high exposure for lesser-known acts that possess the capital to pay for it. Thus, many artists such as Carlos and Anthony are left to choose between sharing scant profits from streams with corporations or doing it themselves but facing the possibility of little to no airplay.

Some established indie labels such as Rhymesayers have signed promotion deals. In 2007, they signed with Warner Music Group and its co-founder Brent "Siddiq" Sayers stated that, after the deal, they had access to all the services of companies under Warner's ILB umbrella (Scholtes 2007). Macklemore and Ryan Lewis signed a similar promotion deal with ADA (Smith 2012), who provided assistance in their airplay and promotion for a flat monthly fee. In 2016, Chance the Rapper paired with Apple Music to exclusively release his album Coloring Book for two

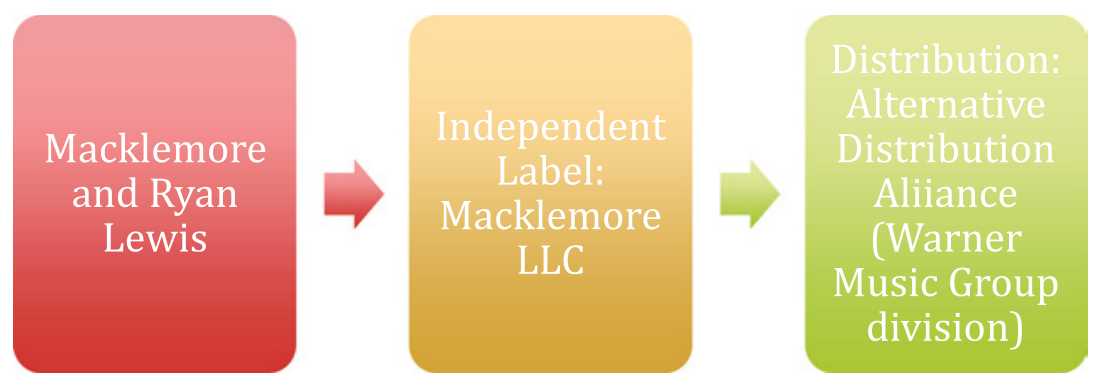

Fig. 4.2 Macklemore and Ryan Lewis' distribution model 
weeks and became the first "streaming only" album to chart on Billboard 200. While remaining unsigned, Chance has been alternatively sponsored by other large businesses such as Apple, Bud Light, and CitiBank to become commercially successful (Austen 2016; Best et al. 2017; Phillips 2017). Other major corporations such as Live Nation (Live Nation 2013) and potentially Spotify (Resnikoff 2017) are attempting to create their own record labels to circumvent the control of the traditional three major labels. In essence, many independent acts rely on various large corporations to become commercially successful despite promoting DIY ethics.

As a result, slightly more than $20 \%$ (ten) of listeners argue that it has become more evident that rappers work with large corporations when it is in their mutual best interest (Suhr 2011). As Pathik writes, "independent artists now need the help of major companies to be commercially successful in our society today." Nathan S (2015) writes of the rise of nicknamed "mindie" rappers, or indie rappers who are secretly aided by big companies. He lists Kevin Gates, Skizzy Mars, and most notably Logic as examples. Funk Volume's CEO Damien Ritter (Nathan 2015) argues that these acts are promoted as indie even though they already have relations with large marketing and promotion companies to aid their success. Once they "organically" and "independently" reach financial and commercial success, they leave their "indie" status to join the label affiliated with those marketing and promotion companies. In essence, numerous musicians negotiate terms for mutually beneficial outcomes by turning indie music into a fetishized commodity to generate profits (Ostrove 2014).

Ultimately, my study indicates that listeners view major and independent hip-hop as fluid and constantly changing, which leads to a mixed space rather than binary oppositions. My findings show that there is a pull and push dynamic. Listeners believe that many musicians frequently navigate the mixed space as they try to maintain economic and creative freedom while attempting to stay culturally relevant and financially profitable. Also, interviewees state that the term indie has changed over time. They argue that hip-hop's indie movement of the early 2000s focused on anti-corporate sentiments. Following 360-degree contracts and the reassertion of technology by the majors, current independent musicians focus on online distribution and social media to circumvent their control. Yet major label and independent artists remain highly intertwined and dependent upon one another in complex ways, which makes the term "indie" a constantly evolving term for listeners today. 


\section{Conclusion}

Interviews indicate that the distinction between majors and independents are still meaningful in hip-hop's culture. As Immortal Technique famously said on "Industrial Revolution" (2003a) about his rise as a rapper: "stuck in the underground, a general that rose to the limit, without distribution managers, a deal, or a gimmick." Immortal Technique's rise to fame is indicative of numerous musicians who willingly choose to remain indie. Listeners claim that access to economic and cultural resources remains a key issue in the hip-hop community. Additionally, they raise issues of authenticity, citing that indie rappers are better able to create music aligned with listeners' social locations and experiences of race and class, and in some instances gender and sexuality. The results show that many female and LGBTQA listeners believe that a large majority of musicians remain sexist, heteronormative, and homophobic in their lyrics despite having progressive views of race and class in the USA. Yet for respondents like Sierra, hip-hop still has the potential to address pertinent social issues relevant to her social life, such as "racial discrimination, gender inequality, poverty, and LGBTQ rights."

Nonetheless, the concept of "indie" has frequently been questioned by listeners. As Immortal Technique raps on 2003s "Crossing the Boundary" (2003b), "you're only minor "til your major." At times, listeners and the broader hip-hop community have even declared the "death" of indie hip-hop. Interviewees suggest that the categories indie and major are not binary because so many artists operate in a mixed space with blurred lines wherein independent and major companies remain highly intertwined. For example, listeners mention that indie musicians are frequently pulled and pushed into the mainstream as they attempt to be financially successful.

The definition of "indie" has changed over time as it faces waves of commodification and resistance. This has become more evident with the rapid advances in technology, namely the utilization of the Internet to distribute music and promote social media. This most recent change has created new problems for hip-hop culture, as it searches to find itself among a dispersed group of artists and listeners (Karubian 2009). Listeners are well aware that the majors and indies coexist and are codependent upon one another in the music industry. As Andrews (2006) states, "independent culture can survive...though the definition might remain ever-changing." 


\section{REFERENCES}

A-Trak. 2014. "Why 2014 Was One of the Best Years for Rap: The Left Field Seeped Out of the Margins and into the Mainstream." Retrieved April 15, 2016. www.medium.com/cuepoint/why-2014-was-one-of-the-best-years-forrap-4-ecab5b0ecf\#.kj6dx5wp.

Ahmed, Insanul. 2011. "Interview: Lupe Fiasco Hates His Own Album." Retrieved April 15, 2016. http://www.complex.com/music/2011/02/ interview-lupe-fiasco-hates-lasers.

Alim, Samy, Jooyoung Lee, and Lauren Mason Carris. 2010. "'Short FriedRice-Eating Chinese MCs' and 'Good-Hair-Havin Uncle Tom Niggas': Performing Race and Ethnicity in Freestyle Rap Battles." Journal of Linguistic Anthropology 20 (1): 116-133.

Andrews, Catherine. 2006. "If It's Cool, Creative and Different, It's Indie." Retrieved April 15, 2016. http://www.cnn.com/2006/SHOWBIZ/ Music/09/19/indie.overview/.

Asante, Molefi Kete. 2008. It's Bigger Than Hip Hop: The Rise of the Post-HipHop Generation. New York: St. Martin's Press.

Austen, Ben. 2016. "The New Pioneers: Chance the Rapper Is One of the Hottest Acts in Music, Has a Top 10 Album and His Own FestivalAll Without a Label or Physical Release." Retrieved January 1, 2018. https://www.billboard.com/articles/news/magazine-feature/7468570/ chance-the-rapper-coloring-book-labels-grammys.

Baker, Soren. 2014. "50 Cent Leaves Interscope: How Nas, Busta Rhymes, Ghostface Killah \& Mos Def Fared After Leaving Their Longtime Label Homes." Retrieved April 15, 2016. http://hiphopdx.com/news/id.27806/ title.50-cent-leaves-interscope-how-nas-busta-rhymes-ghostface-killah-mosdef-fared-after-leaving-their-longtime-label-homes.

Basu, Dipannita, and Pnina Werbner. 2001. "Bootstrap Capitalism and the Culture Industries: A Critique of Invidious Comparisons in the Study of Ethnic Entrepreneurship." Ethnic and Racial Studies 24 (2): 236-262.

Bechtel, Craig. 2016. "Knowledge Drop: The Evolution of Del the Funky Homosapien." Retrieved April 15, 2016. http://music.newcity. com $/ 2016 / 05 / 05 /$ knowledge-drop-the-evolution-of-del-the-funky-homosapien/.

Best, Cassidy, Katie Braile, Emily Falvey, Samantha Ross, Julia Rotunno, and David Schreiber. 2017. "A 'Chance' of Success: The Influence of Subcultural Capital on the Commercial Success of Chance The Rapper." Journal of the Music \& Entertainment Industry Educators Association 17 (1): 31-58.

Biondo, Michael. 2012. "Strange Music's Social Media Marketing May Have a Hand in Their Success." Retrieved April 15, 2016. http://www. mainstreethost.com/blog/strange-musics-social-media-marketingmay-have-a-hand-in-their-success/. 
Bootleg Kev. 2012. "Macklemore Talks L.A. Reid Trying to Sign Him \& Atmosphere Comparisons w/ Bootleg Kev." Retrieved April 15, 2016. https://www.youtube.com/watch?v=ojDlOSymbbk.

Burgess, Omar. 2012. “Today's Mathematics: How Hip-Hop Measures Commercial Success." Retrieved April 15, 2016. http://hiphopdx.com/ editorials/id.2023/title.todays-mathematics-how-hip-hop-measurescommercialsuccess.

Caramanica, Jon. 2017. “The Rowdy World of Rap's New Underground: The Lo-Fi Rap That Thrives on SoundCloud Teems with Unruly Energy. Can It Survive the Mainstream?" Retrieved January 1, 2018. https://www.nytimes. com/2017/06/22/arts/music/soundcloud-rap-lil-pump-smokepurrp-xxxtentacion.html.

Carter, Sophia. 2014. "Rainbow Noise Entertainment-Turning Music Upside Down.” Retrieved April 15, 2016. http://vadamagazine.com/entertainment/ music/rainbow-noise-entertainment.

Cooper, Roman. 2009. "MURS Leaves Warner Bros., Talks New Projects." Retrieved April 15, 2016. http://hiphopdx.com/news/id.9829/title. murs-leaves-warner-bros-talks-new-projects.

Drake, David. 2015. "If It Ain't About the Money: Does Hip-Hop Still Need Major Labels?” Retrieved April 15, 2016. www.complex.com/ music/2015/01/hip-hop-major-labels-2015.

Folami, Akilah. 2007. "From Habermas to Get Rich or Die Tryin: Hip-Hop, the Telecommunications Act of 1996, and the Black Public Sphere." Michigan Journal of Race and Law 12: 235-304.

Forman, Murray. 2000. "Represent: Race, Place, and Space in Rap Music." Popular Music 19 (1): 65-90.

Forman, Murray. 2010. "Conscious Hip-Hop, Change, and the Obama Era." American Studies Journal 54: 1-20.

Fox, Mark. 2004. "E-commerce Business Models for the Music Industry." Popular Music and Society 27 (2): 201-220.

Frazier, Walter. 2010. "Lupe Fiasco Drops Label Beef to Focus on 'Lasers'." Retrieved April 15, 2016. http://www.billboard.com/articles/ news/948646/lupe-fiasco-drops-label-beef-to-focus-on-lasers.

Gosa, Travis. 2010. "Not Another Remix: How Obama Became the First HipHop President." Journal of Popular Music Studies 22 (4): 289-415.

Gottfried, Gideon. 2014. "Fragmentation of the Music Industry: Everything Is Falling Apart-Luckily.” Retrieved April 15, 2016. www.imusiciandigital. $\mathrm{com} / \mathrm{en} / \mathrm{blog} /$ fragmentation-of-the-music-industry.

Greenburg, Zach O' Malley. 2015. “Revenge of the Record Labels: How the Majors Renewed Their Grip On Music.” Retrieved April 15, 2016. http://www.forbes.com/sites/zackomalleygreenburg/2015/04/15/ revenge-of-the-record-labels-how-the-majors-renewed-their-grip-on-music/. 
Greene, Talib Kweli. 2015. "Why I Left the Major Label System: And a Little Bit of What I've Learned in the Music Biz." Retrieved April 15, 2016. https:// medium.com/cuepoint/why-i-left-the-major-label-system-a0ecfa06ae9l\#. 60 fmop8ap.

Gupta-Carlson, Himanee. 2010. "Planet B-Girl: Community Building and Feminism in Hip-Hop." New Political Science 32 (4): 515-529.

Harkness, Geoff. 2012. "True School: Situational Authenticity in Chicago's HipHop Underground." Cultural Sociology 6 (3): 283-298.

Harrison, Anthony Kwame. 2006. “Cheaper Than a CD, Plus We Really Mean It: Bay Area Underground Hip Hop Tapes as Subcultural Artefacts." Popular Music 25: 283-301.

Hesmondhalgh, David. 1999. "Indie: The Institutional Politics and Aesthetics of a Popular Music Genre." Cultural Studies 13 (1): 34-61.

Hess, Mickey, 2012. “The Rap Career.” In That's the Joint: The Hip Hop Studies Reader, edited by Murray Forman and Marc Anthony Neal, 634-654. New York: Routledge.

Hibbett, Ryan. 2005. "What Is Indie Rock?" Popular Music and Society 28 (1): 55-77.

Hip Hop Since 1987 TV. 2013. "Brother Ali Talks Being Independent, 90s Business Model Being Popular Today \& more.” Retrieved April 15, 2016. https://www.youtube.com/watch?v=eYK0lc_gwTw.

Hunter, Margaret. 2011. "Shake It, Baby, Shake It: Consumption and the New Gender Relation in Hip-Hop.” Sociological Perspectives 54 (1): 15-26.

Immortal Technique. 2003a. "Industrial Revolution." Revolutionary Vol. 2. Viper Records.

Immortal Technique. 2003b. “Obnoxious." Revolutionary Vol. 2. Viper Records. Jeffries, Michael. 2011. Thug Life: Race, Gender, and the Meaning of Hip-Hop. Chicago: University of Chicago Press.

Jones, Steve. 2002. "Music That Moves: Popular Music, Distribution and Network Technologies." Cultural Studies 16 (2): 213-232.

Karubian, Sara. 2009. "360 Deals: An Industry Reaction to the Devaluation of Recorded Music." Southern California Interdisciplinary Law Journal 18: 395-462.

Knab, Christopher. 2004. "How and Why Major Labels and Independent Labels Work Together." Retrieved April 15, 2016. http://www.musicbizacademy. com/knab/articles/majorindie.htm.

Leyshon, Andrew, Peter Webb, Shaun French, Nigel Thrift, and Louise Crew. 2005. "On the Reproduction of the Musical Economy After the Internet." Media, Culture and Society 27 (2): 177-209.

Live Nation. 2013. “Live Nation's Artist Nation Introduces G-Major Lead by Veteran Artist Manager Virginia Davis." Retrieved January 1, 2018. http://investors.livenationentertainment.com/news-center/ 
news-center-details/2013/Live-Nations-Artist-Nation-Introduces-G-MajorLead-By-Veteran-Artist-Manager-Virginia-Davis/default.aspx.

Lopes, Paul. 1992. "Innovation and Diversity in the Popular Music Industry: 1969-1990." American Sociological Review 57 (1): 56-71.

Mansbridge, Jane, and Aldon Morris. 2001. Oppositional Consciousness: The Subjective Roots of Social Protest. Chicago: University of Chicago Press.

Markman, Rob. 2011. "Killer Mike Talks Reconciling with Big Boi." Retrieved April 15, 2016. http://www.mtv.com/news/1662818/killer-mike-big-boi/.

Markman, Rob. 2013. "Chief Keef's Interscope Deal Revealed to Be Worth \$6 Million." Retrieved April 15, 2016. http://www.mtv.com/news/1700678/ chief-keef-recording-contract/.

Marshall, Lee. 2013. "The 360 Deal and the 'New' Music Industry." European Journal of Cultural Studies 16 (1): 77-99.

McLeod, Kembrew. 2005. "MP3s are Killing Home Taping: The Rise of Internet Distribution and Its Challenge to the Major Label Music Monopoly." Popular Music and Society 28 (4): 521-531.

Moore, Marcus. 2015. "MURS: Have a Nice Life." Retrieved April 15, 2016. http://pitchfork.com/reviews/albums/20622-have-a-nice-life/.

Moore, Ryan. 2007. “Friends Don't Let Friends Listen to Corporate Rock: Punk as a Field of Production.” Journal of Contemporary Ethnography 36 (4): 438-474.

Morgan, Marcyliena, and Dionne Bennett. 2011. "Hip-Hop \& the Global Imprint of a Black Cultural Form." Dedalus: the Journal of the American Academy of Arts \& Sciences 140 (2): 176-196.

Myer, Letrez, and Christine Kleck. 2007. "From Independent to Corporate: A Political Economic Analysis of Rap Billboard Toppers." Popular Music and Society 30 (2): 137-148.

Nathan S. 2015. "Your Favorite Indie Rapper is Secretly Signed to a Major Label." Retrieved April 15, 2016. http://djbooth.net/news/entry/ indie-rapper-secretly-signed-major-label.

Nguyen, Hao. 2015a. "How Tech N9ne Became the Top Independent Hip-Hop Artist in the Game Today." Retrieved April 15, 2016. http://www.stopthebreaks.com/independent-case-studies / how-tech-n9ne-became-top-independent-hip-hop-artist-game-today/.

Nguyen, Hao. 2015b. "Independent Hip-Hop Record Label Profile: 300 Entertainment." Retrieved April 15, 2016. http://www.stopthebreaks. com/independent-case-studies/independent-hip-hop-record-label-profile-300-entertainment/.

Ollison, Rashod. 2008. "MURS Goes Mainstream." Retrieved April 15, 2016. http://articles.baltimoresun.com/2008-10-30/entertainment/ 0810280109_1_murs-for-president-rapper-major-label.

Ostrove, Geoffrey. 2014. “The Political Economy of Financially Successful Independent Artists." Class, Race and Corporate Power 2 (1): 1-22. 
Oware, Matthew. 2014. “(Un)Conscious (Popular) Underground: Restricted Cultural Production and Underground Rap Music.” Poetics 42: 60-81.

Paine, Jake. 2013. "Logic Signs to Def Jam Records, NO I.D. to Executive Produce Album." Retrieved April 15, 2016. http://hiphopdx.com/news/ id.23588/title.logic-signs-to-def-jam-records-no-i-d-to-executive-producedebut-album/.

Peisner, David. 2015. "Why the Rap Veterans Behind Atlanta Indie Label Quality Control Music Are the Smartest Guys in Hip-Hop.” Retrieved April 15, 2016. http://www.billboard.com/articles/news/6443743/qualitycontrol-smartest-guys-in-hip-hop.

Peters, Mitchell, and Chris Martins. 2016. "Watch Dr. Dre Welcome Anderson. Pak to Aftermath Roster." Retrieved April 15, 2016. http://www.billboard. com/articles/columns/hip-hop/6859424/dr-dre-anderson-paak-comptonmalibu-aftermath-entertainment.

Phillips, Amy. 2017. “Chance the Rapper Explains How He's Still Independent, Despite Apple Music Deal.” Retrieved January 1, 2018. https://pitchfork. com/news/71701-chance-the-rapper-explains-how-hes-still-independent-despite-apple-music-deal/.

Pough, Gwendolyn. 2004. Check It While I Wreck It: Black Womanhood, HipHop Culture, and the Public Sphere. Boston, NH: Northeastern University Press.

Raymer, Miles. 2013. “Cakes Da Killa: The Eulogy.” Retrieved April 15, 2016. http://pitchfork.com/reviews/albums/17684-the-eulogy/.

Resnikoff, Paul. 2017. "How to Get Signed by Spotify Records." Retrieved January 1, 2018. https://www.digitalmusicnews.com/2017/03/20/getsigned-spotify-records/.

Reynolds, Daniel. 2015. “The Exclusive Interview with Mykki Blanco You've Been Waiting For.” Retrieved April 15, 2016. http://www.hivplusmag.com/ people/2015/10/08/mykkis-mad-genius.

Rose, Tricia. 2008. The Hip Hop Wars: What We Talk About When We Talk About Hip Hop-And Why It Matters. New York: Basic Civitas.

Scholtes, Peter. 2007. "Rhymesayers Sign Deal with Warner." Retrieved April 15, 2016. http://www.citypages.com/music/rhymesayers-sign-deal-with-warners6620729.

Schwartzberg, Lauren. 2014. "Lesbian Hip-Hop Hits Primetime." Retrieved April 15, 2016. https://www.vice.com/en_us/article/out-comes-thelesbian-rap-ballad-456.

Sehgal, Kabir. 2018. "Spotify and Apple Music Should Become Record Labels so Musicians Can Make a Fair Living." Retrieved January 1, 2018. https:// www.cnbc.com/2018/01/26/how-spotify-apple-music-can-pay-musicians-more-commentary.html. 
Sköld, David, and Alf Rehn. 2007. “Makin’ It, by Keeping It Real Street Talk, Rap Music, and the Forgotten Entrepreneurship from 'the Hood.'" Group of Organization Management 32 (1): 50-78.

Smith, Clyde. 2012. "The Heist: Macklemore \& Ryan Lewis Take DIY Route to iTunes \#1." Retrieved April 15, 2016. http://www.hypebot.com/hypebot $/ 2012 / 10 /$ the-heist-macklemore-ryan-lewis-take-diy-route-to-itunes-1.html.

Smith, Clyde. 2013. “The Major 'Exposure' of Macklemore and the Myth of the Indie Artist.” Retrieved April 15, 2016. http://www.hypebot.com/hypebot/2013/02/ the-exposure-of-macklemore-and-the-myth-of-the-indie-artist.html.

Stahl, Matt, and Leslie Meier. 2012. “The Firm Foundation of Organizational Flexibility: The 360 Contract in the Digitalizing Music Industry." Canadian Journal of Communication 37: 441-458.

Stern, Bradley. 2016. "Mykki Blanco Is Right: Gay Media Has an Inclusivity Problem." Retrieved April 15, 2016. http://popcrush.com/mykki-blancogay-media-inclusivity-problem/.

Strachan, Robert. 2007. "Micro-Independent Record Labels in the UK." European Journal of Cultural Studies 10 (2): 245-265.

Suhr, Hiesun. 2011. "Understanding the Hegemonic Struggle Between Mainstream Vs. Independent Forces: The Music Industry and Musicians in the Age of Social Media." International Journal of Technology, Knowledge and Society 7 (6): 123-136.

The NE Hip-Hop. 2015. “Aesop Rock \& Rob Sonic Talk Soundset, Indy HipHop Today, Upcoming Solo Projects \& More!” Retrieved April 15, 2016. https://www.youtube.com/watch?v=Z8Pf2eBDR-8.

XXL Staff. 2008. "The \#6 Biggest Moment: Cash Money Signs with Universal." Retrieved April 15, 2016. http://www.xxlmag.com/xxl-magazine/2008/02/the-6-biggest-moment-cash-money-signs-with-universal/.

Open Access This chapter is distributed under the terms of the Creative Commons Attribution 4.0 International License (http://creativecommons.org/ licenses/by/4.0/), which permits use, duplication, adaptation, distribution and reproduction in any medium or format, as long as you give appropriate credit to the original author(s) and the source, a link is provided to the Creative Commons license and any changes made are indicated.The images or other third party material in this chapter are included in the work's Creative Commons license, unless indicated otherwise in the credit line; if such material is not included in the work's Creative Commons license and the respective action is not permitted by statutory regulation, users will need to obtain permission from the license holder to duplicate, adapt or reproduce the material.

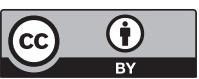

